\title{
Aphrodisiac Effect of Aqueous Stem Bark Extract of Ficus Sycomorus on Female Wistar Rats
}

\author{
*U. Tijjani, M. I. Mabrouk, I. U. Yarube, M. Muhammad \\ Department of Human Physiology, Faculty of Basic Medical Sciences, College of Health Science, Bayero University Kano, Nigeria. \\ [“Corresponding Author: E-mail: tijjaniummi@gmail.com; : : +2348063464214]
}

\section{ABSTRACT}

In the present study, the effect of aqueous stem bark extract of Ficus sycomorus was evaluated on female sex hormones and sexual behavior in female Wistar rats. Adult female rats having regular estrous cycle confirmed by daily cytology of the vaginal smear analysis were used. Rats were randomly divided into 3 groups ( $\mathrm{n}=10$ ): Group I served as a control; while group II, and III received $40 \mathrm{mg} / \mathrm{kg}$ and $80 \mathrm{mg} / \mathrm{kg}$ of the extracts respectively. The results revealed significant increase $(p<0.5)$ in serum concentration of the estradiol in group II and a significant decrease $(p<0.5)$ in serum concentration of estradiol in group III in comparison with the control. There was also significant decrease $(p<0.5)$ in serum level of progesterone in group II and no significant effect in group III in comparison with the control. The result also indicated no significant effect $(p>0.5)$ of the extract on female sexual behavior, which may suggest no scientific basis for the use of the extract as an aphrodisiac in females.

Keywords: Ficus sycomorus, Aphrodisiac, Estradiol, Progesterone, Lordosis quotient

\section{INTRODUCTION}

The use of medicinal plants for health reasons is as old as humanity (Ephrian et al., 2008). The wakefulness of the role of medicinal plants in health care delivery in developing countries has led to increasing need for research in traditional medicine, with a prospect of incorporating it into modern medicine (Sofowara, 1993). This is very essential as $70 \%$ of Nigerian population depends on traditional medicine (Tanvir et al., 1994.) This rate tends to be higher in African countries due to high dependency on medicinal plants for their health care needs (Erhabor et al., 2013).

Ficus sycomorus, "Baure" (Hausa) or "Epin" (Yoruba), is a medicinal plant belonging to Moraceae, consisting of about 40 genera and over 1000 species of trees, shrubs, vines and herbs usually found near streams in the Savannah area (Sofowara, 1993). It is mostly used in Nigeria, South Africa, Kenya, Somalia and other parts of Africa as extract of stem-bark, roots, leaves and fruits. F. sycomorus has numerous traditional as well as medicinal benefits. It is used in the treatment of jaundice, snake bites, dysentery, chest pain, cough and throat infections (Sofowara, 1993). Phytochemical studies have identified the presence of saponins, alkaloids and flavonoids in the stem bark of F.sycomorus (Marriott, 1994). Aqueous extract of F.sycomorus stem bark and other parts of the plant have been reportedly used traditionally to treat infertility and sterility in humans and animals in parts of Africa (Pakia and Cookie, 2003; Kone and Atindehou, 2008).

Over a long period of time, people have devised ways to derive sexual desire, to improve sexual health and techniques. This has led to the emergence and application of substances called aphrodisiacs (Gundidza et al., 2009; which are drugs, foods, scents or devices that can arouse or increase sexual drive or libido. Most aphrodisiacs carry out their function either by altering the level of specific neurotransmitters or specific sex hormones such as progesterone, testosterone and estrogen in the body (Alok et al., 2013).

Preliminary studies have established some of its effects including anti-oxidative and antibacterial activities (Alphonsine et al., 2012); sedative and anti-convulsant (Sandabe, 2002); anti-diabetic 
property (Njagi et al., 2012) as well as analgesic effects (Sandabe and Kwari, 2000). Mythical information from Northern Nigeria reveals the usage of aqueous stem bark extract of Ficus sycomorus as aphrodisiac, with no known scientific literature that substantiates or refutes the acclaimed effect. In the light of the above, this study was designed to evaluate the aphrodisiac effect of the extract on sex hormones and sexual behavior in female Wistar rats.

\section{MATERIALS AND METHODS}

\section{Plant Identification and Authentication}

Fresh stem-bark of Ficus sycamorus was obtained from Dosan, Dawakin Kudu Local Government of Kano State, Nigeria in August, 2015. The plant was identified by a Botanist at the Department of Biological Sciences, Bayero University, Kano, Nigeria; and assigned herbarium accession number 'Bukhan 0109'.

\section{Extract Preparation}

Fresh stem bark was cut into pieces and shadedried. The dried stem bark was grinded into powder using a grinding machine; $3 \mathrm{~kg}$ of the ground powder was dissolved in 15 litres of distilled water. The mixture was refluxed and filtered with Whatman filter paper №1. The filtrate was heated in an oven at $45^{\circ} \mathrm{C}$ till it gets dried-up (Igbokwe et al., 2010). The filtrate yielded $80 \mathrm{~g}$ of the dried extract which was used for the experiment.

\section{Experimental Animals}

Fourty eight (48), 3-4 months old female Wistar rats were used for this research. The animals were obtained from animals' house of Physiology Department Bayero University, Kano. The animals were housed in a plastic cage at room temperature monitored under normal photoperiod and fed with standard animal feed and water ad libitum.

\section{Acute Toxicity Study}

Lorke (1983) method was used to determine the median lethal dose $\left(L_{50}\right)$. Thirteen female rats were used in two phases.
First phase: Nine (9) rats were used. They were sub-divided into three groups of three animals each $(\mathrm{n}=3)$; and administered with $10 \mathrm{mg} / \mathrm{kg}, 100$ $\mathrm{mg} / \mathrm{kg}$ and $1000 \mathrm{mg} / \mathrm{kg}$ of Ficus sycomorus extract, respectively. Animals were observed for 24 hours for any sign of toxicity and mortality. All the animals in sub-group I (1000 mg/kg) died; two, in sub-group II (100 mg/kg) died, while none of the animals died in sub-group III (10 mg/kg ).

Second phase: The results obtained from the first phase determined the doses to be given in the second phase, which were $20 \mathrm{mg} / \mathrm{kg}, 40 \mathrm{mg} / \mathrm{kg}$, $80 \mathrm{mg} / \mathrm{kg}$ and $160 \mathrm{mg} / \mathrm{kg}$, respectively. Animals given $160 \mathrm{mg} / \mathrm{kg}$ died within 24 hours of the $2^{\text {nd }}$ phase. The $\mathrm{LD}_{50}$ was calculated as the geometric mean of the maximum dose producing $0 \%$ mortality and the minimum dose producing $100 \%$ mortality.

\section{Experimental Design}

Thirty (30) adult female Wistar rats were randomly divided into 3 groups of ten (10) animals each $(n=10)$.

Group I served as control group, and received distilled water.

Group II received $40 \mathrm{mg} / \mathrm{kg}$ of the extract.

Group III received $80 \mathrm{mg} / \mathrm{kg}$ of the extract.

Prior to grouping of animals, estrous cycle of each rat was monitored for two weeks, only those with regular 4-days estrous cycle were selected for this study. The phases of the estrous were determined according to the method of Bakare et al. (2012), based on cytology of vaginal smears obtained daily in the morning $(9-10 \mathrm{am}) .10 \mu \mathrm{l}$ of normal saline solution was drawn into a micro pipette and emptied into rats' vagina. After a few seconds a mixture of normal saline solution and vaginal fluid was suctioned using pipette, dropped on glass slide covered with a cover slip and examined under the microscope.

Phases were identified based on the predominant cell present on glass slides. Pro-estrous (1st phase of the cycle) was identified by the presence of predominately nucleated epithelial 
cells; estrous phase (2nd phase of the cycle), by predominantly anucleated cornified cells with irregular shapes; meta-estrus (3rd phase of the cycle) by same proportion of leucocytes, cornified and anucleated epithelial cells; and the last phase of the cycle, di-estrous by predominance of leucocytes.

After oral administration of the extract for two weeks, rats were decapitated after being anaesthetised with ketamine injection $40 \mathrm{mg} / \mathrm{kg}$ intraperitoneally. Blood samples were collected in plain bottles and centrifuged at $3000 \mathrm{rpm}$ and the sera aspirated and used for hormonal analyses (Adebayo, 2015)

\section{Determination of Lordosis Quotient}

An improvised unilateral pacing chamber apparatus was used to study lordosis quotient as basis for sexual behavior. The procedure for the development usage of the apparatus was carried out in accordance with Pfaus et al., 2004 in which the chamber was partitioned by a divider that contains a small hole allowing only the female to pass through. A red dim light was placed above the chamber to enhance sexual behavior, and a sexually experienced male was introduced to the female and allowed to acclimatised for $5 \mathrm{~min}$ at their respective estrus phases. The females solicited sexual contact by entering the male chambers, and after a series of pacing along the male chamber they then received mounts from the male after which they returned to their chambers for seconds. The whole event was videotaped for 30 minutes and the lordosis quotient was then calculated as a measure of sexual receptivity accordingly.

\section{Hormonal Assays}

The serum level of estradiol and progesterone were analyzed using enzyme linked immunosorbent assay (Elisa) kits by the method of Tietz (1995) following the manufacturer's manual.

\section{Data Analysis}

Values were expressed as mean \pm standard error of mean (S.E.M). All data were analyzed using statistical package for social sciences (SPSS) version 20.0 software. One way ANOVA followed by Turkey post hoc test was used to compare mean values for statistical significance. Values of $P<0.05$ were considered significant.

\section{RESULTS}

\section{Acute Toxicity Study}

The aqueous extract of Ficus sycomorus is characterized by less toxicity according to scale proposed by Lorke (1983) as the $\mathrm{LD}_{50}$ of the extract was found to be $89 \mathrm{mg} / \mathrm{kg}$.

Table 1 shows the effect of Ficus sycomorus extract on the levels of serum progesterone, serum estradiol and lordosis quotient in control and experimental groups of rats. Extract administration at $40 \mathrm{mg} / \mathrm{kg}$ (group II) significantly $(p<0.05)$ decrease serum levels of progesterone and increase serum level of estradiol in comparison with control (group I) respectively. There is also significant $(p<0.05)$ increase in progesterone and decrease in estradiol at 80 $\mathrm{mg} / \mathrm{kg}$ (group III) in comparison with $40 \mathrm{mg} / \mathrm{Kg}$ (group II) respectively. There is no significant difference between the high dose (group III) and low dose (group II) of the extract on lordosis quotient comparison with the control [Table 1].

Table 1: Effect of Ficus sycomorus on serum level sex hormones and sexual behavior.

\begin{tabular}{llll}
\hline PARAMETER & GROUP I & GROUP II & GROUP III \\
\hline Progesterone $(\mathrm{ng} / \mathrm{ml})$ & $28.10 \pm 2.41^{\mathrm{a}}$ & $18.00 \pm 0.35^{\mathrm{a}, \mathrm{b}}$ & $29.00 \pm 2.00^{\mathrm{b}}$ \\
Estradiol $(\mathrm{pg} / \mathrm{ml})$ & $297.00 \pm 38.18^{\mathrm{a}}$ & $549.40 \pm 23.64^{\mathrm{a}, \mathrm{b}}$ & $244.60 \pm 13.90^{\mathrm{a}, \mathrm{b}}$ \\
Lordosis quotient & $56.00 \pm 8.94$ & $54.00 \pm 11.40$ & $58.00 \pm 8.37$ \\
\hline
\end{tabular}

Values expressed as (Mean \pm S.E.M, $n=30$ ). aMean differences is statistically significant compared to control (group I). ${ }^{b}$ Mean differences is statistically significant when $80 \mathrm{mg} / \mathrm{kg}$ (group III) compared with $40 \mathrm{mg} / \mathrm{Kg}$ (group II). 


\section{DISCUSSION}

The results obtained revealed significant increase $(p<0.5)$ in mean value $(549.40 \mathrm{pg} / \mathrm{ml})$ of serum concentration estradiol in $40 \mathrm{mg} / \mathrm{Kg}$ of Ficus sycomorus (group II) and a significant decrease $(p<0.5)$ in mean value $(244.60 \mathrm{pg} / \mathrm{ml})$ of serum concentration estradiol in $80 \mathrm{mg} / \mathrm{Kg}$ of Ficus sycomorus (group III) in comparison with mean value $(297.00 \mathrm{pg} / \mathrm{ml})$ of the control (group l). There was also significant decrease $(p<0.5)$ in mean value $(18.00 \mathrm{ng} / \mathrm{ml})$ of serum level progesterone in $40 \mathrm{mg} / \mathrm{Kg}$ of Ficus sycomorus (group II) and no significant effect in mean value $(29.00 \mathrm{ng} / \mathrm{ml})$ of serum level progesterone in 80 $\mathrm{mg} / \mathrm{Kg}$ of Ficus sycomorus (group III) in comparison with mean value $(28.10 \mathrm{ng} / \mathrm{ml})$ of the control (group I). The result also indicated no significant effect ( $p>0.5)$ in mean value (54.00) of the extract at $40 \mathrm{mg} / \mathrm{kg}$ (group II) and mean value (58.00) of $80 \mathrm{mg} / \mathrm{Kg}$ (group III) on female sexual behavior in comparison with mean value (56.00) of the control (group I).

Although there is an increased acceptance and utilisation of medicinal plants worldwide, many are used without resource to any safety (Melanie, 1999). However, they are generally considered to be safe and effective agents (George, 2011). Several researches have indicated that chemical substances including plant extracts could interfere with the concentration and function of sex hormones (Benie et al., 2003). Several studies have revealed many physiological importance of aqueous stem bark of Ficus sycomorus, some of which includes; antioxidative and antibacterial effects (Alphonsine et al., 2012), sedative and anticonvulsant properties, anti-diabetic and analgesic effects (Njagi et al., 2012; Sandabe and Kwari, 2000). The results of this study have shown the $L D_{50}$ of the extract as well as its effect on sex hormone and sexual behavior.

\section{Acute Toxicity Study}

The acute toxicity study provides information on the adverse effects of a single dose of a drug or substance within $24 \mathrm{hrs}$ following oral or dermal administration (Lorke, 1983). The calculated $\mathrm{LD}_{50}$ from this study was $89 \mathrm{mg} / \mathrm{kg}$, signifying low toxicity of the extract (Lorke, 1983). This is in contrast with that of Sandabe, 2002 who used same plant and reported $L D_{50}$ to be $720 \mathrm{mg} / \mathrm{kg}$. Variation in $L D_{50}$ value of same plant might be due environmental difference (Lorke, 1983), sex variation, and routes of administration as oral administration was reported to be about 100 times less toxic than intraperitoneal (Sener et al., 1998).

\section{Effect of Ficus sycomorus Extract on Serum Concentration of Progesterone}

The result revealed significant reduction of serum levels of progesterone by low dose $(40 \mathrm{mg} / \mathrm{kg}$ ) of Ficus sycomorus extract, and this effect might be as a result of inhibition of luteinizing hormone of the anterior pituitary (Blank et al., 2006). It could also be as a result of the alkaloids present in the plant which agrees with findings of Yakubu et al. (2008) who reported that the alkaloid component of $C$. aconitifolious may be behind the reduction in serum progesterone levels, same was reported for the following plants with alkaloidal component: Senna alata leaves (Yakubu et al., 2010), Alchornea cordifolia (Lembe et al., 2014), Dioscorea villosa (Atsukwi, 2015). More so, alkaloids have been reported to inhibit the synthesis of cellular progesterone (Goize et al., 1996). The ability of the extract to reduce progesterone levels may have a resultant effect of conception in females with impairment of ovulation. This is in agreement with the work of Sulaiman et al. (2007), which revealed that decreased progesterone levels in combined effects of aqueous extract of Lepidegathis longifolia and Phyllagathus rotundifolia in pseudopregnant and non-pregnant rats is responsible for failure of conception. Altogether, the above may refute the traditional use of the extract for the treatment of infertility and sterility in humans (Pakia and Cooke, 2003; Kone and Atindehou, 2008). The increase in progesterone level observed at a higher dose at estrus phase could be due to positive feedback mechanism on the pituitary to release gonadotropic hormones which 
stimulate granulosa cells to increase production of progesterone.

Progesterone is essential for the regulation of normal female reproductive functions. Its major roles being; induction of ovulation, facilitation of implantation and maintenance of early pregnancy, development of mammary glands (Graham and Clarke, 1997), neuro-behavioural expression of sexual behaviour, and serving as a precursor molecule for androgen synthesis (Genazzani et al., 2000).

Lordosis quotient is strictly dependent on sexual steroids, since it is abolished by ovariectomy but easily reversed by estrogen followed after an appropriate time interval by progesterone (Abdulwaheb et al., 2006). The feedback inhibition of gonadotropin releasing hormone (GnHR) secretion by progesterone provides the basis for most widely-used form of contraception. This process prevents mid-cycle surge of leutanising hormone (LH) and ovulation, which could impair the endometrium function leading to alteration in special protein necessary for nourishment of implanted fertilized egg with adverse effect on prenatal development. In addition, this may encourage menstruation and luteolysis (Yakubu et al., 2010).

\section{Effects of Aqueous Extract of Ficus sycomorus on Serum Concentration of Estradiol}

The significant increase of estradiol at low dose may be as a result of increase in gonadotropin released by direct stimulation of accessory sex organs. This agrees with the work of Mishra et al. (2009), which showed the estrogenic activity of aphrodisiac plant Bougainvillea spectables leaves being connected to folliculogenesis. Folliculogenesis refers to increase in growth and development of follicles with resultant increase in estrogen secretion from follicular cells. Increase in estradiol levels could also be related to the phytoestrogen, saponin, present in the extract which is believed to be an estrogen precursor (Gauthamen et al., 2000). Phytoestrogens are non-steroidal compounds present in plants which are structurally similar to natural estrogen making it possible for its binding with estrogen receptors, thereby inducing biologically detectable effects (Setchell et al., 1984; Navarro, 2005), hence increasing estradiol levels (Shahin et al., 2008; Contero et al., 2015; Poorfand et al., 2013; Ogbuehi, 2015). This may suggest that at low doses, the extract may enhance sexual desire due to its potential to increase serum estradiol (Thornton and Finn, 1999; Uphouse and Maswood, 1999; Roder et al., 2009; Adams and Ratto, 2013; James and Zachry, 2013). However, at a higher dose $(80 \mathrm{mg} / \mathrm{kg})$, there was a significant reduction in serum estradiol which may be as a result of negative feedback effect on the pituitary to inhibit gonadotropic hormone secretion (Messinis et al., 2015). Some researchers have used low doses of estrogen when stimulation of sexual behaviour was expected and high doses when inhibition was predicted (Ellingsen and Agmo, 2004).

Estradiol, a potent metabolite of estrogen predominately in reproductive age has displayed a wide range of reproductive effect in mammalian target tissue (Hewitt and Korach, 2002). It is known to induce responses in the reproductive process in reproductive tract, mammary tissue (Hewitt and Korach, 2002). Estrogen is known to increase sexual desire (Thornton and Finn, 1999; Uphouse and Maswood, 1999), and also acts in a feedback mechanism, influencing the production of follicle stimulating hormones (FSH) from the pituitary gland. $\mathrm{FSH}$ in turn promotes the development of the immature ovarian follicles, which increases the production of estrogen from the ovary (Yakubu et al., 2008). Estrogenicity may account for premature opening of vagina and its cornification and it is known that the administration of estrogen produces uterotrophic effects in several animal species including rats and mice. These effects are associated with growth and proliferation of the endometrial cells number, vaginal opening and cornification (Rifai et al., 2001). Due to their utero-trophic effects, estrogens have been reported to accelerate the 
passage of ova through the uterine tubes and the uterus, the premature expulsion of eggs is presumed to be the basis of their anti-conceptive activity. Furthermore, the disruption of the estrogen/progesterone balance may result in an unfavorable endometrial environment for receptivity, since degeneration at the implantation site has been demonstrated in animals (Nwaforet al., 2013). These observations taken together showed that the extract possessed estrogenic activity.

Although data is not found on the same plant but other aphrodisiac plant from different species have been shown to have this estrogenic effects; some of these plants include - hydroalcaholic extract of dichotoma (Sharma et al., 2015), Cinifuga racemosa (Shahin et al., 2008), Ilex gualouyes (Contero et al., 2015), Aloe vera extract (Poorfrand et al., 2013). Nonetheless, a previous study by Sandabe, 2002 has reported phytochemical screening of the Ficus sycomorus extract to contained flavonoids and alkaloids, bioactive compounds that possess effects on reproductive system. These two compounds (flavonoids and alkaloids) were reported to possess anti-fertility activities (Gupta et al, 2003; Nataraj et al., 2007). These further lent credence to the anti-fertility effects of the extract.

\section{Effect of Aqueous Extract of Ficus sycomorus on Female Sexual Behaviour}

Lordosis quotient is the most important indicator of female receptivity (Kagathara et al., 2015) and the most frequently used parameter for assessing the effect of hormones and drugs on female sexual behaviour in rodent (Uphouse, 2000; Uphouse and Guptarak, 2010). However, from the result of this study, lordosis quotient did not significantly change across the doses of the extract. This is not surprising as receptivity measured as lordosis quotient have been reported to increase with appropriate hormonal stimulation (Power, 1970). The findings are in contrast with the work of Nwafor et al. (2012) who reported that lordosis quotient significantly increased with a corresponding decrease in lordosis latency as a result of extract with estrogenic property.

Female rat sexual behaviour is tightly linked to ovulation and the synchronous timing for both events is controlled by the hypothalamicpituitary-gonadal (HPG) axis with estrogen as the ultimate conductor. Unlike primates, normally cycling female rats show sexual receptivity only during the proestrus and Estrus (ovulatory) portion of the reproductive cycle (Sarkar et al., 2008) associated with a rise in progesterone and estrogen.

In rodents, a combination of estradiol and progesterone is most effective in stimulation of female sexual behaviour (James, 2007). However, this study revealed significant increase in estradiol coupled with a decrease in progesterone at low dose of the extract and at high dose significant decrease in estradiol and increase in progesterone; the combined action of which are paramount in induction of sexual receptivity (Lordosis quotient) than increase in one hormone alone (Power, 1970).

\section{CONCLUSION}

The aqueous stem-bark extract of Ficus sycomorus has estrogenic and anti-progesterone effects, with no effect on female rat sexual behavior thereby refuting the acclaimed aphrodisiac effects.

\section{ACKNOWLEDGEMENT}

The authors are grateful to all laboratory technical staff in the Department of Human Physiology Bayero University, Kano for the role they played in the laboratory work during this research.

\section{REFERENCES}

Abdulwaheb, M., Makonnen, E. and Debella, A. (2006). Effect of catha edulis foresk (khat) extracts on female rat sexual behavior. Pharmacologyonline, 3:143152.

Adams, G.P and Ratto, M.H. (2013). OvulationInducing factor in seminal plasma: a 


\section{Nigerian Journal of Basic and Applied Science (June, 2018), 26(1): 70-79}

review Animal Reproduction Science, 136:148-156

Adebayo, E.M. (2015). Effect oral administration of Decoction on serum levels of levels of Luteinizing Hormone, Progesterone and Estrogen en female Dutch-white Rabbits. Research Journal of Medicinal Plants, 9:141-145.

Alok, S., Retendra, K and Roman deep, S. (2013). Nature a phrodisiacA review of Current Scientific Literature. International Journal of Recent Advances in pharmaceutical Research, 3(2):1-25.

Alphonsine, R.T., Adre, T., Adama, H., Marus, L., Hassanaka, M. K., Odile, G.N and Innocent, P.G. (2012). Antioxidative and antibacterial activity of phenolic compounds from Ficus sur Forrsk and Ficus sycomorus L. (Moracea): potential for sickle cell disease treatment in Burkina Faso. International Journal of Biological and Chemical Sciences, 6(1): 328-336.

Atsukwi, D., Ejike, E. D., Adams, D. M., Tende, A. J., Tope, O. O and Danmallam.L. (2015).Contraceptive effect of ethanolic extract of female Wistar rats. International Journal of Biochemistry Research and Review, 5(2):135.

Bakare, A. A., Bassey, R. B. Koko, I. E., Sanyyaolu A. O., Ashamu, A. E and Ademola, A.O. (2012). Effect of lime juice (Citrus aurantifolia) on Histomorphological Alternation ofthe ovaries and uterus of cyclic SpragueDawley Rat. European Journal of Scientific Research, 67(4):607-616.

Benie, T., Duval, J and Thieulant, M. L. (2003). Effects of some traditional plant extract on rat estrous cycle compared with clomid. Phytotherapy Research, 17(7):748-755.

Contero, F., Abdo, S., Vinueza, D., Moreno, J., Tuquinga, M and Ipaca, N. (2015). Estrogenic activity of ethanolic extracts from leaves of ilex guayusaloes and medicagosativa in Rattusnorvegicus. Pharmacology Online, 2:95-99.

Ellingsen, E and Ågmo, A. (2004).Sexualincentive motivation and paced sexual behaviour in female rats after treatment with drugs modifying dopaminergic neurotransmission. Pharmacology, Biochemistry and Behaviour, 77:431-445.

Ephrian, P., Helana, M. P., Alison, D. P and Robert, A. N. (2008).Ficusspp (Fig) Ethno-botany and potential as anticancer and anticancer and anti-inflammatory agent. Journal of Ethano-Pharmacology, 119(2):123-195.

Erhabor, J.O., Idu, M and Udo, F.O.C. (2013). Ethno-medicinal survey of medicinal plants used in the treatment of male infertility among the IFoNkari people of Ini Local Government Area Akwalbom State, Nigeria. Research Journal of Recent Sciences, 2:5-11.

Gauthamen, K., Adaikan, P.G., Prasan, R.N.V and Ngaji, S.C. (2000).Proevectile Pharmacological effects of Tribulustemestrus extract on the rabbit Corpus cervanosum. Annals of the Academy of Medicine Singopore, 29(1):22-26.

Genazzani, A. R., Stomati, M., Morittu, A., Bernardi, F., Monteleone, P., Casarosa, E., Gallo, R., Salvestroni, C. and Luisi, M. (2000).Progesterone, Progestagens and the central nervous system. Human Reproduction, 15(1):14-27.

George, P. (2011). Toxicity and Safety Profile of Medicinal Plants. Journal of Herb Med Pharmacology, 01(6): 40-44.

Goize, P.M., Porpaczy, Z and Freeman, D.A. (1996). Effect of alkaloid in cigreate smoke on human granulose cell progesterone. Synthesis and cell viability gynecol endocrinology, 10:223-228.

Graham, J. D and Clark, C. L. (1997).Physiological action of progesterone in target tissues. Endocrine Reviews, 18(4):502-19. 
Gundidza, G. M., Mmbengwa, V, M., Magwa, M. L., Ramalivhana, N. J., Mukweroh, N.T., Ndaradzi, $\quad W$ and Samie.A. (2009).Aphprodisiac properties of some Zimbabwean medicinal plants formulation. African Journal of Biotechnology, 8(22):6402-6407.

Gupta, M., Mazumber, U.K., Pal, D.K. and Bhattacharya, S. (2003). Onset of puberty and ovarian steriodogenosis following administration of methanolic extract of CuscutareflexaRoxb.stem and Corchorusolitorius Linn seed in mice. Jouranal of Ethnopharmacology, 89:5559.

Hewitt, S. C and Korach, K. S. (2003). Oestrogen receptor knockout mice: role of estrogen receptors alpha and beta in reproductive tissues. Reproduction, 125:143-9.

Igbokwe, N.A., Igbokwe, I. O and Sandabe, U.K. (2010). Effect of prolonged oval administration of Aqueous, extract of Ficussycomorus stem-bark on testicular size of growing Albino Rat. International Journal of Morphology, 28(4):1315-1322.

James, R.R and Zachary, L. S. (2013).Hormonal Predictors of Sexual Motivation in Natural Menstrual Cycles. Hormones and Behaviour, 63(4):636.

James, W.K. (2007). Biological psychology, Reproductive Behaviour, $12^{\text {th }}$ edn, North Carolina State University: Cengage Learning.

Kagathara, G.V., Shah, K. K and Anand, S.I. (2015).Effect of Methanolic Extract of Seeds of Lepidiumsativum Linn.On proceptive and Receptive Behaviour of Female Rats. International Journal of Pharmacy and Pharmaceutical Research, 4(1):101-112.

Kone, W.M and Atindehou, K. K. (2008).Ethnobotanical Inventory of medicine in Northern Cote d' Ivore (West Africa). Journal. African Journal of Botany, 74:76-84.

Lembe, M.D., Njoh-njoh, E. L., Bend, F.E.,Koloko,I.B.,Oundoum,C.P.Hambe,
M.C., Tchamadeu, C.M., Domkam, J., Dimo, T and Gonzales, F.G. (2014). Antifertility Effects of Aqueous Root Extract of Alchorneacordifolia (Euphorblaceae) on Female Albino Rats. Pharmacology and Pharmacy, 5:838845.

Lorke, D. (1983). A new approach to practical acute toxicity testing. Arctoxicology, 54:275-287.

Marriott, A. (1994). Sex Steroids hormones and cell dynamics in the periodontum Critical Reviews in Oral Biology and Medicine, 5:27-53.

Melanie, J.C. (1999). Herbal Remedies: Adverse Effects and Drug Interactions. American Academy of Family physicians, 59(5):1239-1244.

Messinis, L.,Christina,M., Marina, D., Geoge, A. and Konstantinos, D. (2015). Gonodotropin Surge attenuating factor: A physiological regulator. International Journal of obstetrics and Gynecology 14(1).

Mishra, N., Joshi, S., Tandon, V.L and Munjal, A. (2009). Evaluation of Anti-fertility potential of Aqueous Extract of Bougainvillea spectabilis leaves in Swiss Albino mice. International Journal of Pharmaceutical Sciences and Drug Research, 1(1):19-23.

Nataraj, S.K.M., Puvvada, P.K., Badami, S., Patil, S.B., Kannan, E., Thillainayagam, S., Kodiyalam, C. and Bhojraj, S. (2007). Pre-coital and post-coital antiimplantation and abortifacient activities of Aristolochia bracteolateLamaerial parts. Journal of Natural Medicines, 61:302306.

Navarro, M. C. (2005). Mechanism of action of isiflavonos. Ginecologia $Y$ Obserriciaclinica, 6:159-165.

Njagi, J. M., Piero, M. N., Ngeranwa, J. J. N., Ngagi, E.N.M., Kibiti, C.M., Njue, W. M., Maina, D and Gathumbi, P.K. (2012). Assessment of Antidiabetic potential of Ficussycomoruson aloxan-induced 


\section{Nigerian Journal of Basic and Applied Science (June, 2018), 26(1): 70-79}

diabetic mice, International Journal of diabetic research, 1(4):47-51.

Nwafor, A.P., Expo, E., Udofia, E. E and Smith, E.M. (2012). Effect of Methanol Extract of Piper umbellatumLeaves on contraceptive and sexual Behaviour in Rodents Nigerian, Journal of Pharmaceutical and Applied Science Research, 1(2):1-14.

Nwafor, P. A., Idiong, O.J and Davies, K. (2013). Contraceptive and Sexual behaviour effects of methanol extract of Smilexkraussiana root in rodent. African Journal of Pharmacology and Therapeutics, 2(3):94-100.

Ogbuehi, I. H., Ebong, O.O and Obianime, A. W. (2015). A preliminary study on the effect of Abrusprecatorius Linn on Reproductive parameters in female RattusnorvegicusWistar strain. European Journal of Medicinal Plant, 7(3):156-166.

Pakia, $M$ and Cooke, J.A. (2003).The ethanobotany of midzichenda tribes of the costal forest areas in Kenya. South African Journal of Botany, 74:76-84.

Pfaus, J.G. Shadiack, Van, S. T., Tse, M and Molin off, P. (2004).Selective facilitation of sexual solicitation in the female rat by a melanocortin receptor agonist. Proc Nate Acad Science USA, 101(27):1020110204.

Poorfand, M., Karimi, J.H and Houshmaid, F. (2013).Effect of Aloe vera Sap on Progesterone, estrogen and gonadotropin in female rats. Journal of Jahrom University of Medical Sciences, 10(4):6-10.

Power, J.B. (1970).Hormonal Control of sexual receptivity during the estrous cycle of the rat. Physiology \& Behavior, 5:831-835.

Rifai, N., John, J and Paul, A.B. (2001). Fundamentals and apolipopoteins Philadelphia: WB Saunders Company, 462-493.

Roder, S., Brewer, G and Fink, B. (2009).Mentrual Cycle Shift in women's Self-perception and motivation. $A$ daily report Method. Personality and Individual Difference, 47:616-619.

Sandabe, U.K and Kwari, H.D. (2000).Some aspect of ethovertinary medicine among Kanuri and Bura of Borno. Journal of Borno Museum Society, 44(45): 5-10.

Sandabe, U.K. (2002). Pharmacological and Toxicological studies of Aqueous extract of Ficussymcomorus. Moracea stemback in Laboratory animals Ph.D. Thesis, University of Maiduguri.

Sarkar, J.S., Hiegel, C., Ginis, E., Hilbun, E. and Uphouse, L. (2008).Subchronic treatment with fluoxetine attenuates effect of acute fluoxetine on female rat sexual behaviour. Brain Research, 1190:56-64.

Sener, B., Orhan, E.I and Satayavivad, J. (1998). Antimicrobial Activity Screening of some Alkaloids and the plant Extracts from Amaryllidaceae. Phytotherapy Research, 17(10):1220-3.

Setchell, K.D., Gosselin, S.J., Welsh, M.B., Johston, J.O., Balistreri, W.F., Kramer L.W., Dresser, B.L., Tarr, M.J. (1987).Dietary estrogen a probable cause of infertility and liver disease in captive cheetahs. Gastroenterology, 93:225-233.

Shahin, A.Y., Isma'il, A.M and Zahran, K.M. (2008). Adding phytostrogen to clomiphene Induction in unexplainedFertilitupatierts $\quad-\quad a$ randomzed trial. Reproductive Biomed Online, 16(4):580-588.

Sharma, A. Rani, P. Nitesh, S.M.H., Deswel, $S$ and Sing, S. (2015). Antifertility potential of hydroalcoholic extract of Cordia dichoroma $G$ forst leaves: A folklore medicine used by Meena community in Rajasthan state in India. Asian Pacific Journal of Reproduction, 4(2): 100-195.

Sofowara, A. (1993). Medicinal Plant and traditional medicine in Africa. Spectrum Book Ltd. Ibadan, Nigeria, 289-300.

Sulaiman, S.A., Islam, N., Kapitonova, M.Y and Jamallullail, S.M.S. (2007). Effects of an 
Tijjani et al: Aphrodisiac Effect of Aqueous Stem Bark Extract of Ficus Sycomorus on...................

Indigenous Contraceptive herbal formulation on Gonadotrophs of the pituitary gland of the rat. Malaysian Journal of Medical Sciences, 14(1):23

Tanvir, R., Nawaz, R., Zaidi, A.A and Ruby, S. (1994). Phytochemical screening of medicinal plant belonging Euphorbia ceasepak. Veterinary Journal, 14:159163.

Thornton, J. E. and Finn, P.D. (1999). Estrus in: Encyclopedia of Reproduction. Nigerian Journal of Pharmaceutical and Applied Science Research, 1(2):1-14.

Tietz, N.W. (1995). Clinical guide to laboratory tests, $3^{\text {rd }}$ edition W. B. Saunders, Philadelphia 1-997.

Uphouse, L and Guptarak, J. (2010).Serotonin and sexual behaviour Handbook of behavioural neurobiology of serotonin. Elsevier, 347-365.

Uphouse, L and Maswood, S. (1999). Estrogen Action, Behaviour In: Encyclopedia of
Reproduction. Knobil and Neill. Academic Press, 2:39-64.

Uphouse, L. (2000). Female Gonadal hormones, Serotonin and sexual receptivity. Brain Research Reviews, 33:242-257.

Yakubu, M.T., Adeshina, A.O. Oladiji, A. T., Akayi, M.A., Olayede, O.B. Jimoh, G.A., Olatinwo, A.W.O. and Afolayan, A.J. (2010).Abortifacient Potential of Aqueous Extract of Senna alata leaves in Rats. Journal of Reproduction and Fertility, 21(3):163-177.

Yakubu, M.T., Musbau, A.A., Adenike, T.O., Abdulwaheed, O.O., Abdulfatai, A.A., Monsurat, O.Y., Bamidele, V.O. Taofik, O.S and Moyosove, S.A. (2008). Effect of Cnidoscolousacontifolious(Miller) I.M. Johnston leaf extract on reproductive hormones of female rats. Iranian Journal or Reproductive Medicine, 6(3):149-155. 